\title{
Performance and egg quality of laying hens fed pequi pulp flour
}

Marllon José Karpegianne de Oliveira ${ }^{1}$, Adriano Geraldo ${ }^{2}$, Sara Santana Ramos Lemke ${ }^{2}$, Diogo Alvarenga Miranda $^{3}$, Jean Kaique Valentim ${ }^{4}$, Janaína Palermo Mendes ${ }^{4}$

${ }^{1}$ Universidade Estadual Paulista - UNESP, Jaboticabal, SP. ${ }^{2}$ Instituto Federal de Educação, Ciência e Tecnologia de Minas Gerais - IFMG, Campus Bambuí. ${ }^{3}$ Universidade Federal dos Vales do Jequitinhonha e Mucuri, MG. ${ }^{4}$ Universidade Federal da Grande Dourados - UFGD, MS.

\begin{abstract}
The objective of this study was to evaluate the effects of including pequi pulp flour (PPF) in laying hen diets on performance and egg quality. A total of 240 Hisex Brown strain were randomly assigned into 5 groups and were fed diets containing PPF at the level of $0 \%, 0.125 \%, 0.250 \%, 0.375 \%$, and $0.5 \%$. The experiment lasted 63 days ( 3 periods of 21 days). The variables of performance and egg quality were submitted to linear and quadratic regression analysis at the level of $5 \%$ probability. The outcomes suggest that neither performance nor egg quality was affected $(p>0.05)$ by different levels of PPF. Dietary inclusion of PPF tested in the present study was not sufficient to demonstrate improvement in the productive performance of birds as well as in egg quality. Because of the lack of responses, additional research is needed to evaluate higher levels of PPF in the diets for laying hens.
\end{abstract}

Keywords: alternative feedstuffs; by-product; Caryocar brasiliense; poultry.

\section{Desempenho e qualidade de ovos de galinhas poedeiras alimentadas com farinha da polpa de pequi}

Resumo: O objetivo deste estudo foi avaliar os efeitos da inclusão da farinha de polpa de pequi (FPP) em dietas de galinhas poedeiras sobre o desempenho e a qualidade dos ovos. Um total de 240 galinhas Hisex Brown foram aleatoriamente atribuídas em 5 grupos e alimentadas com dietas contendo FPP ao nível de $0 \%, 0,125 \%, 0,250 \%, 0,375 \%$ e 0,500\%. O experimento durou 63 dias (3 períodos de 21 dias). As variáveis de desempenho e qualidade dos ovos foram submetidas à análise de regressão linear e quadrática no nível de probabilidade de $5 \%$. Os resultados sugerem que o desempenho e a qualidade dos ovos não foram afetados $(p>0,05)$ por diferentes níveis de PPF. A inclusão dietética dao FPP testado no presente estudo não foi suficiente para demonstrar melhora no desempenho produtivo das aves, bem como na qualidade dos ovos. Devido à ausência de respostas, são necessárias pesquisas adicionais para avaliar níveis mais elevados de FPP em dietas para poedeiras.

Palavras-chave: alimentos alternativos; avicultura; Caryocar brasiliense, coprodutos.

\section{Introduction}

In response to concerns about food safety, consumers demand more and more for the quality of the products that they consume. The market for direct egg consumption is influenced by visual characteristics of products that trigger the preference for eggs with darker yolk. In another words, eggs with orange pigmentation result from the deposition of xanthophylls, which belong to the group of carotenoid pigments (VALENTIM et al., 2019). Such feature combined with shells dark brown color of some laying hens (e.g., Isa Brown, Lohmann Brown) reflects an extensive production, or "hillbilly type", becoming the consumer's preference.

Egg yolk colors vary from one country to another or even from region to region. In the United States, the preference is for yolk coloring from 7 to 10 on the RYCF scale (MENDONÇA et al., 2018), while in other countries like in Europe or Asia, it is preferred yolk coloring ranging from 10 to 14 (BITTENCOURT et al., 2019). The product analysis made by consumers associate the observed yolk coloring with vitamins that are egg 
constituents, and at the same time to the laying hen health (MORALECO et al., 2019). Although this has no scientific support, consumers have a great preference for more orange yolk eggs due to the better colors distribution in mixtures where eggs are added, such as in bakery products, pasta making, alcoholic beverages, among others (FERRONATO et al., 2020; SOUZA et al., 2020).

Carotenoids are the natural pigments produced by plants, algae, and photosynthetic microorganisms (TERAMUKAl et al., 2020). Dietary inclusion of feedstuffs with high content of carotenoids has been responsible for the coloring of feathers, skin, and egg yolk (SILVA et al., 2019). The yellow color is typical of carotenes (MENDONÇA et al., 2018). Plant extracts are available in nature and are easy to reproduce and plant, besides being less costly (SOARES et al., 2008). Boka et al. (2014) found that plant extracts have a positive effect due to their antioxidant activity that improves nutrient digestibility and stimulates enzyme secretion, helping to preserve the intestinal microbiota, improving the feed conversion ratio, production, and internal egg quality traits.

Brazil is a country rich in wild flora, being a great center of extractive exploration. In that regard, the Brazilian Cerrado outstands (OLIVEIRA et al., 2016) due to its wide array of flora. The pequi (Caryocar brasiliense Camb.) is a Cerrado tree with high commercial value. Its fruit is usually used and appreciated in regional cuisine, besides having antioxidant activity due to the presence of vitamins $A$ and $E$, and carotenoids (LIMA et al., 2020).

To the best of our knowledge, this is the first study considering the dietary inclusion of pequi pulp flour (PPF) for laying hens. Therefore, the current study was conducted to evaluate the inclusion of PPF up to $0.5 \%$ in the diets of laying hens on performance and egg quality. We hypothesized that the inclusion of PPF would improve the performance and egg quality (especially yolk color).

\section{Methodology}

Pequi pulp flour

To prepare the pequi pulp flour, the pequi pulp was extracted from the fruit and then dried with the ad of forced air circulation greenhouse at $40{ }^{\circ} \mathrm{C}$ for $48 \mathrm{~h}$. In the end, the pulp dry matter was $42 \%$. After drying, the pequi pulp was beaten by an industrial food blender (Camargo, SP, Brazil) and sifted. Thus, according to each treatment, the pequi pulp flour was ready to be added to the diets.

\section{Experimental design, diets, and management}

The study was carried out at the Poultry Facilities of the Federal Institute of Minas Gerais Campus Bambuí (IFMG - Campus Bambuí), Bambuí, MG, Brazil. A total of 35-week-old two hundred and forty Hisex Brown laying hens were randomly assigned in 5 treatments for 63 days, following a completely randomized design There were 6 replicates per treatment. Each replicates consists of 4 laying cages measuring $25 \mathrm{~cm}$ wide $x$ $45 \mathrm{~cm}$ deep $\times 35 \mathrm{~cm}$ high and capacity for 2 hens, therefore, 8 birds per replicate. The cages were equipped with nipple drinkers and trough feeders. The light program consisted of a $16 \mathrm{~h}$ light per day and was kept constant to the end of the experiment. Feed and water were provided for ad libitum consumption.

The dietary treatment groups were the control treatment (basal diet, no PPF; control), a basal diet with $0.125 \%$ PPF, a basal diet with $0.250 \%$, a basal diet with $0.375 \%$ PPF, and basal diet with $0.500 \%$ PPF. All diets were formulated to be approximately isocaloric, isocalcic, and isophophoric and meet or exceed the recommendations of Rostagno et al. (2017). Diets were composed of corn and soybean meal-based. The composition and nutrient concentrations of the experimental diets are presented in Table 1. 
Table 1. Ingredients and nutrient composition of experimental diets (as-fed basis)

\begin{tabular}{|c|c|c|c|c|c|}
\hline Ingredients, \% & Control & $\begin{array}{c}0.125 \% \\
\text { PPF }\end{array}$ & $\begin{array}{c}0.250 \% \\
\text { PPF }\end{array}$ & $\begin{array}{c}0.375 \% \\
\text { PPF }\end{array}$ & $0.500 \% \mathrm{PPF}$ \\
\hline Corn & 58.190 & 58.190 & 58.190 & 58.190 & 58.190 \\
\hline Soybean meal & 28.600 & 28.600 & 28.600 & 28.600 & 28.600 \\
\hline Soy oil & 1.500 & 1.500 & 1.500 & 1.500 & 1.500 \\
\hline Limestone & 4.300 & 4.300 & 4.300 & 4.300 & 4.300 \\
\hline Coarse limestone & 4.400 & 4.400 & 4.400 & 4.400 & 4.400 \\
\hline Salt & 0.450 & 0.450 & 0.450 & 0.450 & 0.450 \\
\hline Dicalcium phosphate & 1.347 & 1.347 & 1.347 & 1.347 & 1.347 \\
\hline Kaolin & 0.800 & 0.675 & 0.550 & 0.425 & 0.300 \\
\hline $\mathrm{PPF}^{1}$ & 0.000 & 0.125 & 0.250 & 0.375 & 0.500 \\
\hline DL-Methionine 99\% & 0.160 & 0.160 & 0.160 & 0.160 & 0.160 \\
\hline L-Lysine 78\% & 0.050 & 0.050 & 0.050 & 0.050 & 0.050 \\
\hline Phytase & 0.003 & 0.003 & 0.003 & 0.003 & 0.003 \\
\hline Mineral premix ${ }^{1}$ & 0.100 & 0.100 & 0.100 & 0.100 & 0.100 \\
\hline Vitamin premix ${ }^{2}$ & 0.100 & 0.100 & 0.100 & 0.100 & 0.100 \\
\hline \multicolumn{6}{|l|}{ Calculated nutrient content } \\
\hline Crude Protein, \% & 17.632 & 17.632 & 17.632 & 17.632 & 17.632 \\
\hline Linoleic acid, \% & 2.127 & 2.127 & 2.127 & 2.127 & 2.127 \\
\hline Calcium, \% & 3.900 & 3.900 & 3.900 & 3.900 & 3.900 \\
\hline Available phosphorus, \% & 0.460 & 0.460 & 0.460 & 0.460 & 0.460 \\
\hline Potassium, \% & 0.692 & 0.692 & 0.692 & 0.692 & 0.692 \\
\hline Sodium, \% & 0.181 & 0.181 & 0.181 & 0.181 & 0.181 \\
\hline Chlorine, \% & 0.305 & 0.305 & 0.305 & 0.305 & 0.305 \\
\hline $\mathrm{ME}, \mathrm{kcal} / \mathrm{kg}$ & 2.773 .96 & 2.773 .96 & 2.773 .96 & 2.773 .96 & 2.773 .96 \\
\hline SID ${ }^{3}$ Lys, \% & 0.889 & 0.889 & 0.889 & 0.889 & 0.889 \\
\hline SID Met, \% & 0.404 & 0.404 & 0.404 & 0.404 & 0.404 \\
\hline SID Met+Cys, \% & 0.649 & 0.649 & 0.649 & 0.649 & 0.649 \\
\hline SID Try, \% & 0.197 & 0.197 & 0.197 & 0.197 & 0.197 \\
\hline SID Thr, \% & 0.601 & 0.601 & 0.601 & 0.601 & 0.601 \\
\hline
\end{tabular}

\footnotetext{
${ }^{1}$ PPF: pequi pulp flour

${ }^{2}$ Mineral Premix composition (per kg of product): manganese $75000 \mathrm{mg}$, iron $50000 \mathrm{mg}$, iode $1500 \mathrm{mg}$, zinc 70000mg, copper $8500 \mathrm{mg}$, cobalt $200 \mathrm{mg}$.

${ }^{2}$ Vitamin Premix composition (per kg of product): vitamins: A $800000 \mu$, B12 1000 mg, D3 $200000 \mu, 15000 \mathrm{mg}, \mathrm{K} 3$ $2000 \mathrm{mg}$, B2 $4000 \mathrm{mg}$, B6 $1000 \mathrm{mg}$, niacin $19900 \mathrm{mg}$, pantothenic acid $5350 \mathrm{mg}$, ac. folic $200 \mathrm{mg}$, selenium $2500 \mathrm{mg}$, antioxidant $100000 \mathrm{mg}$.

${ }^{3} \mathrm{SID}=$ standardized ileal digestible.
}

Hen productivity and egg quality

Different variables related to egg performance and quality were evaluated according to the methodologies of several authors (BITTENCOURT et al., 2019; SELIM; HUSSEIN, 2020; VAN DER HEIDE et al., 2021).

From the beginning ( 35 weeks of age) to the end of the study (44 weeks of age), hen productivity was measured weekly per replicate.
Eggs from each hen group were collected and recorded in spreadsheets twice a day. Eggs that showed deformation in the shell, as well as broken and cracked was considered as egg loss. The viable eggs were calculated by subtracting the total eggs collected from the egg loss. Egg weight was calculated by dividing the total weight by the collected number of eggs. 
Feed intake was measured by subtracting the weight of feed remaining in each hen group from the sum of feed supplied weekly to each hen group. Egg production was calculated by dividing the total number of eggs by the housed hens. Egg mass was calculated by multiplying egg weight by egg production. Feed conversion ratio (FCR) was calculated as a gram of feed intake divided by a gram of egg weight.

Regarding egg quality, in the last week of the study $\left(9^{\text {th }}\right.$ week) all intact eggs produced per replicate were used to perform the specific gravity according to the method proposed by Freitas et al. (2004). The method is based on the Archimedes principle. After analyzing the specific gravity, two fresh eggs per replicate (12 eggs/treatment) were collected randomly from each replicate to perform egg components. Each egg was analyzed individually. First of all, the egg was weighed (digital scale, $0.05 \mathrm{~g}$ ) and then broken. The yolk color was analyzed by a single observer in the same ambient conditions of light by comparison with the color pattern scale (comparative scale from 1 to 15, Yolk Color Fan colorimetric disc). Using a caliper, the albumen height was measured in the middle region of the thick albumen, to determine the Haugh unit. After that, the yolk was carefully removed and then weighed separately.
The shell was washed in running water and was dried at room temperature for $24 \mathrm{~h}$ and then weighted. Albumen weight was calculated by subtracting the sum of yolk and shell weight from the egg weight. The egg components were calculated considering the percentage that each component represents in the egg weight. Shell thickness was measured with the aid of a micrometer (accuracy of $1 \mu \mathrm{m}$ ) at 3 different places around the equator of the shell.

The assumption of the normality of the studentized residuals was checked using the Shapiro Wilk test while Levene's test was used to verify the homogeneity of the variances. When needed, the response variable was transformed into a normal distribution approximation. Regression analysis was performed using linear and quadratic models and outcomes were considered to be significant if $p<0.05$.

\section{Resultados and Discussions}

During the study, no mortality was recorded. There was no effect of different inclusion levels of PPF on the performance and egg quality variables. Only for the variables Shell (\%) and Albumen (\%) that had quadratic effect with value of better inclusion the levels of $0.28 \%$ and 0.278 $\%$, according to the regression equations presented in the table 2 .

Table 2. Performance and egg quality of laying hens fed with different levels of inclusion of pequi pulp flour in the diet.

\begin{tabular}{|c|c|c|c|c|c|c|c|c|}
\hline \multirow{2}{*}{ Items } & \multicolumn{5}{|c|}{ Pequi pulp flour levels } & \multirow[t]{2}{*}{ EPM } & \multirow{2}{*}{$\begin{array}{l}p- \\
\text { linear } \\
\text { value }\end{array}$} & \multirow{2}{*}{$\begin{array}{c}\text { p- } \\
\text { quadratic } \\
\text { value }\end{array}$} \\
\hline & Control & $0.125 \%$ & $0.250 \%$ & $0.375 \%$ & $0.500 \%$ & & & \\
\hline Egg production, $\%$ & 95.69 & 95.19 & 96.77 & 95.60 & 96.16 & 1.026 & 0.680 & 0.872 \\
\hline Feed intake, g/d & 121.53 & 120.04 & 120.80 & 118.14 & 118.93 & 2.395 & 0.699 & 0.900 \\
\hline Fed conversion ratio, kg feed/dz egg & 1.565 & 1.555 & 1.537 & 1.527 & 1.53 & 0.029 & 0.559 & 0.764 \\
\hline Fed conversion ratio, g feed/g egg & 2.038 & 2.011 & 1.999 & 1.982 & 1.968 & 0.049 & 0.654 & 0.910 \\
\hline Egg weight, g & 62.44 & 62.74 & 62.49 & 62.48 & 63.16 & 0.565 & 0.787 & 0.634 \\
\hline Viable eggs, \% & 99.75 & 99.11 & 99.19 & 99.63 & 99.24 & 0.234 & 0.497 & 0.329 \\
\hline Specific gravity, $\mathrm{g} / \mathrm{cm}^{3}$ & 1.091 & 1.091 & 1.091 & 1.090 & 1.092 & 0.001 & 0.882 & 0.169 \\
\hline Yolk color & 4.62 & 4.97 & 4.87 & 5.07 & 4.82 & 0.162 & 0.333 & 0.142 \\
\hline Yolk, \% & 24.39 & 24.65 & 24.91 & 24.99 & 24.47 & 0.293 & 0.596 & 0.113 \\
\hline Shell, \%* & 9.48 & 10.04 & 9.99 & 9.71 & 9.86 & 0.102 & 0.185 & 0.007 \\
\hline Albumen, \% & 66.13 & 65.3 & 65.1 & 65.3 & 65.67 & 0.295 & 0.324 & 0.013 \\
\hline Shell thickness, mm & 0.464 & 0.477 & 0.477 & 0.466 & 0.474 & 0.073 & 0.699 & 0.465 \\
\hline Haugh unit & 94.57 & 93.77 & 94.90 & 93.88 & 95.05 & 1.160 & 0.770 & 0.684 \\
\hline
\end{tabular}

$2^{*}$ quadratic effect $(P<0.05)$; Regression equation: Shell $(\%): Y=9,579+2,777 x-4,864 x^{2} ; R^{2}: 87.59 \%(0.28 \%$ inclusion). Albumen (\%): $Y=66.088-7.190 x+12.897 x^{2} ; R^{2}: 97.04 \%$ (0.278 \% inclusion). 
Egg production was not influenced ( $p>0.05$ ) by the addition of PPF. The result is in agreement with Silva et al. (2000) that investigating the effects of the inclusion of annatto extract as a source of carotenoids on egg yolk pigmentation did not observe a significant difference in production. Likewise, Fassani et al. (2019) do not report effects of annatto extract as a natural source of carotenoids not even synthetic commercial pigments Carophyll ${ }^{\circledR}$ Yellow and Red $(20+10 \mathrm{ppm})$ and $(15+30 \mathrm{ppm})$ on production performance. According to Valentim et al. (2019), the use of natural pigments has been increased due to the needs of customers in developed countries, who banned the use of synthetic pigment additives, such as canthaxanthin and astaxanthin in humans as well as in animal feed.

With the different inclusions of PPF in the feed, the variations in feed intake among different treatments were not significant. We believe that this fact can be explained by the nonvariation of palatability, color appearance, and other variables since these factors are important for the determination of birds' feed intake. These results are in agreement with Oliveira et al. (2016) who studied the inclusion of different levels of pequi peel flour in diets for Japanese quail and also do not observe any difference in feed conversion, corroborating with our results, although we work with the pulp instead of peel.

The feed intake influences the average egg weight due to the direct effect of the daily nutrient consumption such as protein, sulfur amino acids, and fatty acids. Since the nutrient composition of the diets was similar and the feed intake at different levels of PPF inclusion was the same, the average egg weight remained in the same range, without difference among treatments.

The high egg viability in all treatments with no statistical differences can be justified by the correct feed formulation. The diets offered to laying hens through the experiment period had no interference in any of the PPF inclusion levels on egg viability. Furthermore, the adequate levels of minerals (mainly calcium and phosphorus) ensured the correct shell formation with high quality, consequently improving the egg viability.

The specific gravity was not altered at different levels of PPF. Our results are in agreement with the study of Garcia et al. (2002) which report that the inclusion of $10 \%$ of canthaxanthin (carophyll Red) did not influence the performance and egg quality (e.g., specific gravity) of commercial laying hens.

Pequi (Caryocar brasiliense) is an important source of carotenoids and has $7.25 \mathrm{mg}$ $100 \mathrm{~g}^{-1}$ fruit of carotenoids (SILVA et al., 2016). Carotenoids from pequi have been described as compounds that act as natural pigments (UENOJO; JUNIO; PASTORE, 2007). Thus, it was expected that the provision of a diet with PPF would increase the intensity of pigmentation of egg yolk. However, regardless of the inclusion level, no improvement in egg yolk color was observed. Our outcomes disagree with Valentim et al. (2020) which reported that the addition of pigments from plant extracts containing carotenoid in the feed for quail improves the yolk color.

No references are found on the use of PPF in the nutrition of laying hens. Based on experiments with annatto extract (EU), we observed that perhaps the level of inclusion of PPF may have been low, not reaching even $50 \%$ of the minimum significant level in comparison with the EU.

Other works such as Carvalho et al. (2006) demonstrate that the presence of carotenoids in the diet for laying hens has significant gains in the yolk color. Although the pequi pulp contains different types of carotenoids (anthexanthena, zeaxanthin, violaxanthin, and lutein) as identified by AzevedoMeleiro and Rodriguez-Amaya (2004), they were not sufficient to influence in the yolk colorat the level proposed in the current research.

The yolk percentage, and shell thickness, are in agreement with Silva et al. (2000) which do not observe the effect of annatto extract supplementation in these variables.

According to Carvalho et al. (2006), the Haugh unit will vary according to the source used for carotenoids. The use of marine sources such as seaweed demonstrates significant results, improving the internal quality of the eggs, going against that obtained in the current study where PPF was used as a source of carotenoids. Perhaps this improvement can be attributed to the properties of the seaweed, not just to the carotenoids.

Oliveira et al. (2016) indicated that pequi peel flour can be used in commercial diets for laying quail in up to $3 \%$, maintaining poultry 
productivity, improving yolk color, and reducing egg production costs.

Several studies (BITTENCOURT et al., 2019; SILVA et al., 2019; VALENTIM et al., 2020) report the effectiveness of alternative pigmenting sources to those commonly used (FASSANI et al., 2019). However, the inclusion of PPF may not have been enough to demonstrate its action.

\section{Conclusion}

The levels of pequi pulp flour tested in the present study were not sufficient to demonstrate improvements on the performance of laying hens as well as on the egg quality, especially in the yolk color. Further research with higher inclusion percentages is necessary to evaluate the effectiveness of this natural additive.

\section{Ethics and biosafety committee}

The project was submitted and approved under protocol number 05/2017 of UNIFENAS.

\section{References}

AZEVEDO-MELEIRO, C. H.; RODRIGUEZ-AMAYA, D. B. Confirmation of the identity of the carotenoids of tropical fruits by HPLC-DAD and HPLC-MS. Journal of food Composition and Analysis, v. 17, n. 3-4, p. 385-396, 2004. https://doi.org/10.1016/i.jfca.2004.02.004

BITTENCOURT, T. M.; LIMA, H. J. D. A.; VALENTIM, J. K.; MARTINS, A. C. D. S.; MORALECO, D. D.; VACCARO, B. C. Distillers dried grains with solubles from corn in diet of japanese quails. Acta Scientiarum. Animal Sciences, v. 41, 2019. https://doi.org/10.4025/actascianimsci.v41i1.427 $\underline{59}$

BOKA, J.; MAHDAVI, A. H.; SAMIE, A. H.; JAHANIAN, R. Effect of different levels of black cumin ( $\mathrm{N}$ igella sativa L.) on performance, intestinal $\mathrm{E}$ scherichia coli colonization and jejunal morphology in laying hens. Journal of animal physiology and animal nutrition, v. 98, n.2, p.373-383, 2014. https://doi.org/10.1111/jpn.12109

CARVALHO, P. R.; PITA, M. C. G.; PIBER-NETO, E.; MIRANDOLA, R. M. S.; MENDONÇA-JÚNIOR, C. X. Influência da adição de fontes marinhas de carotenóides à dieta de galinhas poedeiras na pigmentação da gema do ovo. Brazilian Journal of Veterinary Research and Animal Science, v.
43, n.5, p.654-663,

2006.

https://doi.org/10.11606/issn.1678-

4456.bjvras.2006.26575

FASSANI, E. J.; ABREU, M. T.; SILVEIRA, M. M. B. $M$. Coloração de gema de ovo de poedeiras comerciais recebendo pigmentante comercial na ração. Ciência Animal Brasileira, v. 20, 2019. https://doi.org/10.1590/1089-6891v20e-50231

FREITAS, E. R.; SAKOMURA, N. K.; GONZALEZ, M. M.; BARBOSA, N. A. A. Comparação de métodos de determinação da gravidade específica de ovos de poedeiras comerciais. Pesquisa Agropecuária Brasileira, v. 39, n. 5, p. 509-512, 2004. https://doi.org/10.1590/S0100204X2004000500014

FERRONATO, C.; BITTENCOURT, T. M.; LIMA, H. J. D.; VALENTIM, J. K.; MARTINS, A. C. S.; SILVA, N. E. M. Farelo de algodão na dieta de codornas japonesas. Boletim De Indústria Animal, v. 77, p. 1-8, 2020.

https://doi.org/10.17523/bia.2020.v77.e1468

GARCIA, E. A.; MENDES, A. A.; PIZZOLANTE, C. C.; GONÇALVES, H. C.; OLIVEIRA, R. P.; SILVA, M. A. Efeito dos níveis de cantaxantina na dieta sobre o desempenho e qualidade dos ovos de poedeiras comerciais. Brazilian Journal of Poultry Science, v.4, n.1, 2002. https://doi.org/10.1590/S1516$\underline{635 \times 2002000100007}$

LIMA, J. R.; SOUZA, A. C. R. D.; MAGALHÃES, H. C. R.; PINTO, C. O. Pequi Kernel oil extraction by hydraulic pressing and its characterization. Revista Brasileira de Fruticultura, v.42, $\quad$ n.5, 2020. https://doi.org/10.1590/0100-29452020456

MENDONÇA, A. S. A.; CORREA, R. E. A.; BENEVIDES, P. R.; MOTA, A. V.; ABREU FRANCA, E. B. Pigmentante alternativo para gema em ovos de galinha caipira no município de Garrafão-doNorte/PA. Cadernos de Agroecologia, v. 13, n. 2, p. 10-10, 2018.

MORALECO, D. D.; VALENTIM, J. K.; SILVA, L. G.; LIMA, H. J. D. Á.; BITENCOURTT, T. M.; DALLAGO, G. M. Egg quality of laying hens fed diets with plant extracts. Acta Scientiarum. Animal Sciences, v.41, 2019. https://doi.org/10.4025/actascianimsci.v41i1.438 $\underline{01}$ 
OLIVEIRA, M. C. D.; SILVA, D. M. D.; MARCHESIN, W. A.; ATTIA, Y. A. E. W.; LIMA, S. C. O.; OLIVEIRA, H. C. Pequi peel flour in diets for Japanese quail. Acta Scientiarum. Animal Sciences, v. 38, n.1, p.101-106, 2016. https://doi.org/10.4025/actascianimsci.v38i1.283 $\underline{81}$

SILVA, J. H. V. D.; ALBINO, L. F. T.; GODÓI, M. J. D. S. Efeito do extrato de urucum na pigmentação da gema dos ovos. Revista Brasileira de Zootecnia, v. 29, n. 5, p. 1435-1439, 2000. https://doi.org/10.1590/S1516$\underline{35982000000500022}$

SILVA, A. D. L.; LAGE, R. R. P.; FARIA FILHO, D. E. D.; AZEVEDO, I. L.; DIAS, A. N.; FARIA, D. E. D. Pequi peel meal in laying hen diet. Acta Scientiarum. Animal Sciences, v. 38, n. 2, p. 151154, 2016. https://doi.org/10.4025/actascianimsci.v38i2.292 $\underline{40}$

SILVA, N. E. M. E.; LIMA, H. J. D.; VALENTIM, J. K.; TOSSUÉ, F. J. M.; BITTENCOURT, T. M.; VELARDE, J. M. D. S. Banana leaf in the diet of laying hens in cage free system. Acta Scientiarum. Animal Sciences, v. 41, p. e46908-e46908, 2019. https://doi.org/10.4025/actascianimsci.v41i1.469 $\underline{08}$

SOARES, NILCE M.; TUCCI, EDNA C.; GUASTALLI, ELIZABETH A. L.; YAJIMA, HELENA. Controle da infestação por Ornithonyssus sylviarum (Canestrini e Fanzago, 1877) (Acari: Macronyssidae) em poedeiras comerciais utilizando extrato de Azadirachta indica. Revista Brasileira de Parasitologia Veterinária, v. 17, n.4, p. 175-178, 2008. https://doi.org/10.1590/S1984$\underline{29612008000400001}$

SOUZA, A. V.; MORAIS, M. V. M.; ROCHA, M. C.; SOUZA, R. M.; VALENTIM, J. K.; PIETRAMALE, R. T. R.; LIMA, H. J. D. Á. Influence of fennel in Japanese Quail Diet over egg quality and behavior aspects. Boletim De Indústria Animal, v. 77, p. 113 , 2020. https://doi.org/10.17523/bia.2020.v77.e1477

ROSTAGNO, H. S.; ALBINO, L. F. T.; HANNAS, M. I.; DONZELE, J. L.; SAKOMURA, N. K.; PERAZZO, F. G.; BRITO, C. O. Tabelas brasileiras para aves e suínos. Composição de alimentos e exigências nutricionais, v. 17, p. 186, 2017.

SELIM, S.; HUSSEIN, E. Production performance, egg quality, blood biochemical constituents, egg yolk lipid profile and lipid peroxidation of laying hens fed sugar beet pulp. Food chemistry, v. 310, 125864,

2020. https://doi.org/10.1016/j.foodchem.2019.12586 $\underline{4}$

TERAMUKAI, K.; KAKUI, $\quad$ S.; BEPPU, F.; HOSOKAWA, M.; MIYASHITA, K. Effective extraction of carotenoids from brown seaweeds and vegetable leaves with edible oils. Innovative Food Science \& Emerging Technologies, v. 60, p. 102-107, 2020. https://doi.org/10.1016/j.ifset.2020.102302

UENOJO, M.; JUNIO, M. R. M.; PASTORE, G. M. Carotenóides: propriedades, aplicações e biotransformação para formação de compostos de aroma. Química Nova, v. 30, n. 3, p. 616-622, $2007 . \quad$ https://doi.org/10.1590/S0100$\underline{40422007000300022}$

VALENTIM, J. K.; BITTTENCOURT, T. M.; LIMA, H. J. D.; MORALECO, D. D.; TOSSUÊ, F. J. M.; SILVA, N. E. M.; SILVA, L. G. Pigmentantes vegetais e sintéticos em dietas de galinhas poedeiras Negras. Boletim de Indústria Animal, v. 76, p. 19,

2019.

https://doi.org/10.17523/bia.2019.v76.e1438

VALENTIM, J. K.; BITTENCOURT, T. M.; LIMA, H. J. D. À.; BARROS, F. K. Q.; PEREIRA, I. D. B.; ALMEIDA, G. R. D.; ZIEMNICZAK, H. M. Natural and synthetic pigments in diet of Japanese quails. Acta Scientiarum. Animal Sciences, v. 42, 2020.

https://doi.org/10.4025/actascianimsci.v42i1.473 64

VAN DER HEIDE, M. E.; JOHANSEN, N. F.; KIDMOSE, U.; NØRGAARD, J. V.; HAMMERSH $\emptyset$ J, $M$. The effect of deshelled and shell-reduced mussel meal on egg quality parameters of organic laying hens under commercial conditions. Journal of Applied Poultry Research, v. 30, 1, p.100-119, 2021. https://doi.org/10.1016/j.japr.2020.100119 